\title{
PENGALAMAN ORANG TUA DALAM MERAWAT ANAK DENGAN ATTENTION DEFICIT HYPERACTIVITY DISORDER (ADHD)
}

\author{
Ratih Dwilestari Puji Utami ${ }^{1)}$, Wahyuningsih Safitri ${ }^{2)}$, Christiani Bumi Pangesti ${ }^{3)}$, \\ Nur Rakhmawati ${ }^{4)}$ \\ 1,2,3,4 Universitas Kusuma Husada Surakarta \\ ratihaccey@ukh.ac.id
}

\begin{abstract}
ABSTRAK
Attention Deficit Hyperactivity Disorder (ADHD) merupakan permasalahan perkembangan anak ditandai dengan rendahnya konsentrasi dan aktivitas berlebihan pada anak. Prevalensi ADHD meningkat setiap tahunnya. Berbagai upaya telah dilakukan untuk mengatasi dan menangani permasalahan ADHD. Pendeteksian secara dini diperlukan untuk mengidentifikasi ADHD sehingga pemberian terapi dapat diberikan lebih awal dan dapat mengurangi gejala ADHD, membantu anak berkonsentrasi, serta membantu anak memenuhi kebutuhan perkembangannya. Peran keluarga penting dalam upaya perawatan dan pendeteksian dini adanya ADHD. Tujuan penelitian ini adalah mengeksplorasi pengalaman orangtua merawat anak dengan ADHD. Penelitian ini merupakan penelitian kualitatif deskriptif dengan subjek penelitian sebanyak tujuh ibu yang memiliki anak ADHD diambil melalui teknik snowball sampling. Pengumpulan data melalui indepth interview. Hasil penelitian menunjukkan bahwa gejala dini yang muncul pada anak ADHD adalah keterlambatan dalam kemampuan bersosialisasi dan berkomunikasi, kesulitan mempertahankan kontak mata, hiperaktif, perilaku meniru, perilaku marah, dan keterlambatan motorik halus. Upaya perawatan yang dilakukan orang tua adalah pembatasan akses gadget, diet, penerimaan keluarga, pengawasan, dan terapi.
\end{abstract}

Kata kunci: attention deficit hyperactivity disorder; deteksi dini; perawatan

\begin{abstract}
Attention Deficit Hyperactivity Disorder (ADHD) is a child development problem characterized by low concentration and excessive activity in children. The prevalence of $A D H D$ is increasing every year. Various attempts have been made to overcome and treat the problem of $A D H D$. Early detection is needed to identify $A D H D$ so that therapy can be given early and can reduce ADHD symptoms, help children concentrate, and help children meet their developmental needs. The role of the family is important in the treatment and early detection of ADHD. The purpose of this study was to explore the experiences of parents caring for ADHD children. This research is a qualitative descriptive study, the research subjects are seven mothers who were taken by snowball sampling technique. The data collection using in-depth interview approach. The results showed that the early symptoms that appeared in ADHD children were delays in socializing and communication skills, difficulty maintaining eye contact, hyperactivity, imitating behavior, angry behavior, and fine motor delays. Parenting efforts are limiting access to gadgets, diet, family acceptance, supervision and therapy.
\end{abstract}

Keywords: attention deficit hyperactivity disorder; early detection; treatment

\section{PENDAHULUAN}

Attention Deficit Hyperactive Disorder (ADHD) merupakan salah satu bagian dari anak berkebutuhan khusus dan lebih sering disebut sebagai gangguan hiperaktif. Hiperaktif merupakan kondisi dimana anak mengalami ketidakmampuan dalam memberikan perhatiannya pada sesuatu yang dihadapi secara utuh, dan mudah beralih perhatian dari aktivitas satu ke aktivitas yang lainnya, serta cenderung bergerak terus secara konstan dan tidak bisa tenang. Anak yang terdeteksi ADHD cenderung 

$\begin{array}{lcc}\text { mengalami } & \begin{array}{c}\text { gangguan } \\ \text { kognitif, } \\ \text { perilaku, }\end{array} & \text { sosialisasi } \\ \text { maupun }\end{array}$ komunikasi/bahasa. Penderita ADHD meningkat tiap tahunnya, data CDC tahun 2016 menunjukkan bahwa sebanyak 6,1 juta anak ADHD atau 9,4\% dari populasi di Amerika Serikat (Center for Disease Control and Prevention, 2020). ADHD lebih banyak diderita oleh anak laki-laki $(84,3 \%)$ daripada anak perempuan $(15,7 \%)$ (ADHD Institute, 2021).

Gangguan mental, emosi dan perilaku muncul pada $64 \%$ anak ADHD (Center for Disease Control and Prevention, 2020). Gejala utama ADHD antara lain aktivitas yang berlebihan, tidak bisa diam, senantiasa bergerak, tidak dapat memusatkan perhatian, dan impulsif. Gangguan ini timbul karena gangguan biologis kronis yang mengakibatkan terganggunya fungsi kognitif, sehingga anak mengalami penurunan prestasi belajar, penurunan kemampuan mengingat, gangguan orientasi waktu, hambatan dalam perencanaan, kurang peka terhadap kesalahan dan sering melakukan tindakan tanpa tujuan. Anak ADHD mengalami kesulitan membaca, mengeja, berhitung dan menulis dan gangguan kemampuan berbahasa, selain itu anak juga mengalami hambatan dalam mengendalikan emosi, mudah marah dan mudah frustasi (Novriana, Yanis and Masri, 2014).

Deteksi ADHD berdasarkan tiga gejala utama, yaitu inatensi, hiperaktivitas, dan impulsivitas (Tanoyo, 2013). Keluarga memiliki peran penting dalam mendeteksi dini ADHD hal ini dibuktikan dengan banyaknya instrument pendeteksi ADHD yang melibatkan observasi dari orang tua. Pendekatan yang digunakan dalam penegakkan diagnosa ADHD tidak hanya dilakukan melalui instrumen pengkajian tetapi memerlukan pendekatan yang komprehensif seperti wawancara, pemeriksaan penunjang, maupun pemeriksaan yang lainnya. Penegakkan diagnosis penting untuk menyingkirkan diagnosis banding lainnya, memilih intervensi yang tepat untuk anak, menentukan prognosis, pengobatan dan pengambilan keputusan yang tepat untuk anak (Barkley, 2018).

Perawatan yang diberikan orang tua menentukan kemampuan anak dalam mempelajari kemampuan baru, kemandirian anak, dan pemenuhan kebutuhan dasar. Keberhasilan orang tua dalam merawat atau menyesuaikan diri dengan kondisi anak akan berpengaruh terhadap perkembangan dan kemandirian anak (Subandi and Rusana, 2014).

Berdasarkan pemaparan diatas, penelitian ini bertujuan untuk mengeksplorasi pengalaman orang tua dalam merawat anak dengan ADHD.

\section{METODE PENELITIAN}

Metode penelitian ini menggunakan pendekatan kualitatif fenomenologi yang berdasarkan pada pengalaman hidup ibu dalam melakukan deteksi dini dan merawat anak ADHD dengan pendekatan snowball sampling. Kriteria sampel yang digunakan dalam penelitian ini antara lain: anggota keluarga anak ADHD yang berusia diatas 18 tahun dan berperan sebagai caregiver anak ADHD yang berusia 0-5 tahun, berdomisili di Surakarta, dapat berkomunikasi dengan baik, bersedia mengikuti penelitian dari awal hingga akhir. Teknik pengumpulan data dilakukan dengan wawancara mendalam (indepth interview). Lama rata-rata indept interview \pm 45 menit. Tidak ada partisipan yang drop out.

Pengolahan data dilakukan dengan memindahkan rekaman wawancara kedalam komputer peneliti, setelah itu hasil wawancara ditranskrip, dilakukan koding dan dilakukan penarikan tema, dideskripsikan ke dalam narasi dan diinterpretasi dan memaknai data. Keabsahan penelitian dilakukan dengan member checking, peneliti kembali menemui partisipan 
untuk mengklarifikasi apakah deskripsi telah mencerminkan pengalaman partisipan (Creswell, 2013). Etika penelitian yang diterapkan pada penelitian ini adalah dengan menggunakan inform consent, anonimity, confidentiality, beneficience, justice, dan memberikan hak pada partisipan untuk mengundurkan diri dari penelitian (Afiyati and Rahmawati, 2014).

\section{HASIL DAN PEMBAHASAN}

Berdasarkan analisis data, ada dua topik utama yang didapatkan dari penelitian ini, yaitu: deteksi dini gejala ADHD dan perawatan anak ADHD yang dilakukan orang tua.

Topik pertama adalah deteksi dini tanda gejala ADHD. Tanda gejala dini yang muncul pada anak ADHD antara lain: perilaku tantrum dan mudah marah, keterlambatan motorik halus, perilaku hiperaktif, kesulitan dalam bersosialisasi, keterlambatan kemampuan berkomunikasi atau berbicara, kesulitan mempertahankan kontak mata.

Dari tema yang didapatkan diatas ibu menyampaikan bahwa pada tahun pertama kehidupan anak ADHD ada beberapa gejala ADHD yang mulai tampak yaitu adanya kesulitan anak dalam mempertahankan kontak mata dan gejala ini mulai muncul pada saat anak berusia 3 bulan keatas, anak tidak dapat mempertahankan kontak mata lebih dari 2 detik. Sesuai dengan hasil penelitian lainnya bahwa anak hanya mampu melakukan kontak mata sekitar 2 detik. Kontak mata yang baik akan menjamin fungsi interaksi sosial anak. Melalui kontak mata, interaksi sosial dan transfer informasi dapat dilakukan dengan baik (Resmisari, 2016). Anak tidak berespon terhadap panggilan atau stimulus suara atau perilaku orang-orang disekitarnya. Hal ini diikuti dengan adanya hambatan dalam kemampuan anak dalam berkomunikasi/berbicara yang ditandai dengan adanya bahasa yang sulit dimengerti, babbling yang kurang, banyak diam, berbicara terbalik-balik, sering memberikan respon yang tidak sesuai saat diajak berbicara. Dari partisipan rata-rata mengatakan bahwa anak baru dapat mengucapkan kata pertama pada usia 2,5-3 tahun keatas, dan kalimat yang digunakan cenderung tidak berstruktur. Kalimat merupakan rangkaian kata yang dapat berdiri sendiri dan menyatakan makna yang lengkap, dan mengungkapkan pikiran yang utuh, secara lisan dan tulisan. Kemampuan berbicara anak ADHD tidak terstruktur karena adanya pemanjangan, perbaikan, pengulangan ujaran, senyapan diam, senyapan terisi, dan kilir lidah, sehingga kalimat yang dihasilkan tidak efektif (Fallupi, 2018). Anak hiperaktif sering menyela pembicaraan orang lain. Kalimat yang diungkapkan oleh anak ADHD berupa kalimat deklaratif dan kalimat imperatif dengan struktur dan posisi kalimat yang tidak lengkap. Kalimat deklaratif merupakan kalimat berita yang menyampaikan pernyataan pada orang disekitarnya. Kalimat ini digunakan untuk menyampaikan sesuatu yang diperolehnya melalui pendengaran dan penglihatan. Kalimat Imperatif merupakan kalimat seru yang digunakan untuk menyapa orang lain, kalimat ini sering digunakan anak ADHD untuk meminta bantuan dan melarang (Indayani and Ardhianti, 2014).

Hasil wawancara menunjukkan perkembangan motorik halus cenderung lebih lambat jika dibandingkan dengan motorik kasar. Pada saat anak dapat berjalan dan berlari, anak masih mengalami kesulitan terkait motorik halus, anak kesulitan untuk memegang bendabenda kecil, seperti memegang pensil, mengancingkan baju, dan kegiatan motorik halus lainnya. Hal ini berbanding terbalik dengan motorik kasar anak, dimana anak sering melakukan tindakan hiperaktif seperti berlari, menaiki pagar, 
menghalangi motor dijalan, menaiki motor orang tidak dikenal, tidak bisa diam, dan tidak bisa duduk dalam waktu yang lama, anak menunjukkan perilaku sibuk sendiri dan hiperaktif.

Penelitian lain menyebutkan bahwa anak ADHD memiliki keterlambatan dalam segi motorik halus dibandingkan dengan anak normal lainnya, keterlambatan ini dilihat dari ketidakmampuan anak untuk membuat lengkungan, membuat titik-titik dan memotong kertas (Petrauskas, 2014). Kemampuan motorik halus pada anak ADHD adalah kategori cukup (45\%) (Apriliantina, Tri Peni and Laili, 2019).

Perilaku hiperaktif yang ditunjukkan anak sering menjadi penghambat ketika anak bersosialisasi. Ibu mengeluh bahwa anaknya tidak merespon saat dipanggil, tidak memperhatikan saat diajak mengobrol, tidak memperhatikan saat dinasehati, sibuk bermain sendiri, tidak mau bermain dengan temannya tidak dapat bertahan lama ketika bermain satu permainan. Anak hiperaktif cenderung memiliki aktifitas yang sulit dikontrol, aktif bergerak seakan tidak lelah dan tidak bisa diam. Anak tampak gelisah saat bermain, susah untuk diam, selalu aktif bergerak seperti berlari atau memanjat pada sesuatu dan tidak bisa duduk dengan tenang (Alkaff et al., 2019). Pada sebuah penelitian di sekolah, anak ADHD tidak dapat bertahan duduk kurang dari 2 menit selama 30 menit proses pembelajaran. Ketahanan berdiam diri di tempat duduk dan meninggalkan tempat duduk merupakan perilaku bermasalah disekolah dan mengganggu aktivitas belajar. Anak juga menunjukkan perilaku ketrampilan sosial yang kurang disekolah seperti kurang sopan saat bertanya, bersuara keras, acuh dan menjawab pertanyaan tidak relevan, menyerobot pembicaraan saat diskusi, kurang menyadari kesalahan sendiri, tidak dapat mengikuti perintah verbal (Hasanah, Fatmawati and Marlina, 2018).

Anak ADHD juga sering menunjukkan perilaku meniru, tetapi perilaku ini justru bersifat negatif, karena anak suka meniru kata-kata dan perilaku buruk dari tontonan/stimulus yang didapat. Kekhawatiran terkait adanya meniru perilaku negatif juga dirasakan oleh ibu lainnya pada penelitian yang berbeda (Karimzadeh et al., 2020).

Perilaku marah pada anak ditunjukkan dengan mudah marah, marah saat gadget diambil, memukul saat marah, berteriak, menangis, dan tiduran dimana saja saat marah. Anak ADHD memiliki beberapa perilaku yang tidak terduga, seperti tantrum, dan suasana hati yang berubah-ubah. Sifat keras kepala dan impulsif anak memperparah gejala tantrum. Ketika anak tidak mendapatkan apa yang diinginkan, anak marah dan menunjukkan perilaku tidak empatik. Anak akan menjadi gelisah, amarah yang meledak, berfikir bahwa meraka adalah pribadi yang gagal sehingga menurunkan harga dirinya dan membuat frustasi dan depresi (Hakim, 2020). Alasan perilaku tantrum yang muncul pada anak dipicu oleh keputusasaan. Anak yang mengalami keputusasaan sering menuntut perhatian yang tidak semestinya. Perilaku tantrum muncul akibat dari respon orang tua yang memaksakan kehendak pada anak, ketidak mampuan anak dalam berkomunikasi, dan ketidakkonsistenan orang tua dalam menerapkan aturan (Syamsuddin, 2013).

Anak ADHD mengalami kesulitan dalam berkomunikasi sehingga tidak mampu mengutarakan keinginannya, diperparah dengan perilaku impulsif dan hiperaktif anak yang tidak bisa dikontrol sehingga mengganggu lingkungan sekitar. Orang tua berespon dengan memaksa anak untuk diam dan mengikuti aturan lingkungan yang tidak sesuai dengan keinginan anak, ini memicu anak 
untuk melawan. Kejadian ini biasanya terjadi saat anak berada dilingkungan luar rumah, sedangkan ketika anak berada didalam rumah anak diberikan kebebasan untuk beraktivitas, sehingga aturan yang ditetapkan terkesan tidak konsisten (Syamsuddin, 2013).

Topik yang kedua yang muncul adalah perawatan yang dilakukan orang tua pada anak ADHD terdiri dari beberapa topik, antara lain: pembatasan gadget, diet/pembatasan makanan, penerimaan keluarga, bantuan dalam aktivitas harian anak, pengawasan, terapi, pola asuh orang tua dan hambatan perawatan.

Partisipan mengatakan ada beberapa tindakan yang dilakukan dalam pembatasan anak ADHD terhadap akses gadget, antara lain melarang anak untuk bermain gadget dan pembatasan dalam tontonan televisi, tindakan ini dilakukan karena anak sering meniru perilaku dan perkataan buruk dari gadget yang ditonton. Akses gadget pada anak dapat meningkatkan pelepasan hormon dopamin berlebihan yang menyebabkan penurunan kematangan pre frontal cortex, menimbulkan ketidakmampuan tubuh untuk mengontrol waktu, mengotrol emosi, kontrol diri, tanggung jawab, pengambilan keputusan dan nilainilai moral lainnya, serta meningkatkan perilaku gelisah, sering berkeliaran, meningkatnya gejala hiperaktivitas (Setianingsih, Ardani and Khayati, 2018).

Diet dan pembatasan makanan yang dilakukan partisipan antara lain tidak mengkonsumsi susu, mengganti susu dengan jeruk, tidak memakan cokelat, tidak memakan snack dari sekolah, membawa snack sendiri dari rumah. Beberapa partisipan mengeluhkan kesulitan dalam melakukan pembatasan makanan pada anak seperti pembatasan susu dan makanan bertepung. Hal ini dikarenakan terbatasnya akses tenaga dan ekonomi dalam pengadaan makanan pengganti, sehingga memilih untuk tidak memberikan pembatasan makanan pada anaknya. Dari hasil studi pemberian diet pada anak hanya dilakukan oleh $25 \%$ orang tua. Pelaksanaan diet dipengaruhi oleh pengetahuan, kepatuhan terhadap anjuran dokter dan terapis, perilaku anak yang membaik setelah diet, daya beli, ketrampilan mengolah makanan, akses makanan non diet, dan dukungan keluarga (Camelia, Wijayanti and Nissa, 2019).

Pada awal kehidupan anak, keluarga partisipan cenderung mengalami penolakan terhadap kondisi anak, marah dan kecewa dirasakan oleh keluarga anak. Seiring berjalannya waktu, keluarga mulai menerima kondisi anak dan pasrah kepada tuhan terhadap keadaan dan kondisi anak. Penerimaan pada anak ADHD dipengaruhi oleh beberapa faktor antara lain pemahaman tentang ADHD, harapan yang realistis, dukungan lingkungan, penerimaan masyarakat, bebas dari tekanan emosi, kesuksesan pengasuhan, keberhasilan adaptasi, perspektif diri yang baik, pola asuh, kestabilan konsep diri (Andarul, 2020).

Partisipan memilih untuk melakukan pengawasan dan terapi pada anak. Pengawasan yang dilakukan dilakukan dengan melarang anak melakukan kegiatan tertentu yang tidak sesuai dengan norma yang ada, mengurangi akses ke lingkungan sekitar dengan mengunci pintu atau pagar rumah, melakukan pengawasan ketat terhadap aktivitas anak, membatasi akses gadget dan televisi. Pengawasan orang tua dilakukan untuk memantau aktivitas anak dan memastikan anak melakukan kegiatan yang aman dan menunjukkan perilaku sesuai dengan harapan orang tua. Kesulitan yang dialami orang tua ketika muncul perilaku tantrum anak yang memancing orang tua untuk berespon negatif. 
Partisipan mengikutsertakan anak pada kegiatan terapi, yang dimulai dengan pengkajian atau assessment pada anak dan melakukan terapi setiap $2 \mathrm{x}$ seminggu, terapi yang dilakukan dapat berupa terapi perilaku, terapi okupasi dan terapi wicara. Tidak ada anak yang mendapatkan terapi farmakologis dalam penelitian ini. Pelaksanaan terapi dipengaruhi oleh dua faktor yaitu faktor internal dan faktor external. Faktor internal anak yang menghambat keberhasilan terapi seperti keparahan hiperaktif anak, tantrum/kesulitan mengendalikan emosi, kontak mata yang minim, kesulitan bicara, dan ketidakpatuhan. Faktor eksternalnya adalah kepatuhan terhadap diet, dukungan orang tua, peran orang tua, dukungan terapis, jumlah terapis, kerjasama terapis dengan orang tua, sarana prasarana, dan jadwal terapi (Rizky, Noor and Fadhila, 2020).

Partisipan dan keluarga membantu anak ADHD dalam memenuhi aktivitas harian seperti membantu dalam berpakaian, mandi/hygiene diri, makan-minum, dan toileting. Bantuan dalam berpakaian dapat berupa membalikkan baju, mengancingkan baju, menresletingkan baju/celana, dan menali sepatu. Mandi/hygiene anak dibantu dengan dimandikan, dikeramasi dan bantuan saat menggosok gigi. Aktivitas makan anak sudah mulai dimandirikan, anak sudah makan sendiri dan bantuan diberikan dalam pengambilan makanan. Bantuan toleting yang diberikan pada anak adalah menceboki anak setelah BAB/BAK.

Kemandirian anak ADHD merupakan harapan utama orang tua. Orang tua berharap agar anak ADHD mampu untuk membantu dirinya sendiri dalam kehidupan sehari-hari seperti mampu toileting, makan, minum, berpakaian dan lain-lain secara mandiri dan memiliki keterampilan untuk masa depannya kelak. Anak ADHD diharapkan memiliki keterampilan dalam menolong diri sendiri, keterampilan akademik atau fungsional dan keterampilan vokasional (Astini, Utami and Parwati, 2014). Riset menunjukkan bahwa anak ADHD memiliki kesulitan kategori sedang terkait pemenuhan aktivitas harian, dengan gangguan sebesar 38\% (Irwin et al., 2021). Oleh karena itu dukungan orang tua dalam bentuk bantuan pemenuhan aktivitas harian diperlukan oleh anak.

Pola asuh yang digunakan partisipan untuk mengasuh anak ADHD adalah pola asuh otoriter dan permisif. Pola asuh ini dikombinasi dan digunakan dalam pengasuhan anak. Pola asuh otoriter dilakukan untuk mencegah anak melakukan tindakan yang berbahaya. Bentuk pola asuh otoriter ini antara lain melarang anak untuk melakukan kegiatan tertentu yang bertentangan dengan norma atau tindakan yang membahayakan seperti menghadang kendaraan dijalan dan menaiki motor orang tak dikenal, melarang anak untuk menonton televisi atau tayangan dari gadget, membatasi akses anak dengan lingkungan sekitar seperti mengunci pintu dan pagar, membatasi konsumsi makanan tertentu pada anak, dan melakukan pengawasan ketat terhadap aktivitas anak (Kaunang, Munayang and M.D.Kaunang, 2016).

Pola asuh permisif dilakukan partisipan saat anak melakukan aktivitas bermain yang tidak membahayakan dan dan tidak melanggar norma sekitar dan aktivitas dilakukan pada area yang mampu dikontrol oleh partisipan. Partisipan tidak menerapkan pola asuh demokratis karena keterbatasan anak untuk melakukan kontrol diri terhadap perilaku hiperaktif/ impulsif dan kurangnya kemampuan anak untuk memahami nilai benar dan salah atas tindakan yang dilakukan. Hal ini berbeda dengan penelitian sebelumnya, dimana orang tua menerapkan pola asuh demokratis 
(Kaunang, Munayang and M.D.Kaunang, 2016).

Hambatan yang dialami partisipan dalam mengasuh anak ADHD adalah adanya ketidakpahaman masyarakat dan stigma negatif terhadap anak ADHD. Anak ADHD sering dianggap sebagai anak nakal yang suka bertindak semaunya dan tidak paham terhadap norma dan aturan dimasyarakat. Partisipan juga mengeluhkan adanya perilaku tantrum pada anak yang menghambat proses pengasuhan. Berdasarkan penelitian sebelumnya, ada beberapa hambatan yang dialami orang tua dalam merawat anak ADHD, yaitu kurangnya kemandirian pada anak, sehingga orangtua khawatir jika meninggalkan anak tanpa pengawasan, terbatasnya waktu yang dimiliki salah satu orang tua untuk mendampingi anak menjadi tanggung jawab lebih besar pada orang tua yang berperan sebagai caregiver anak. Emosi yang tidak terkontrol pada anak menjadi penghambat dalam pengasuhan. Persepsi masyarakat yang keliru tentang anak ADHD juga menjadi penghambat bagi anak dan keluarga untuk berinteraksi dengan lingkungan sekitar. Permasalahan finansial keluarga menjadi hambatan dalam akses terapi dan pelayanan kesehatan lainnya (Astini, Utami and Parwati, 2014).

\section{KESIMPULAN}

a. Tanda gejala dini yang muncul pada anak ADHD antara lain : kesulitan mempertahankan kontak mata di tahun awal kehidupan anak, tanda ini dapat terdeteksi pada saat anak berusia 3 bulan keatas; keterlambatan kemampuan berkomunikasi atau berbicara ditandai dengan munculnya bahasa yang sulit dimengerti, babbling yang kurang dan anak cenderung diam; keterlambatan motorik halus, anak cenderung mengalami kesulitan saat memegang benda-benda kecil, mengancingkan baju, dan kegiatan yang memerlukan keterampilan motorik halus lainnya; kesulitan dalam bersosialisasi, kesulitan bersosialisasi tampak pada tidak adanya respon anak terhadap stimulus, panggilan, suara, gerakan dan yang lainnya pada awal kehidupan anak; perilaku hiperaktif, anak tampak sibuk sendiri dan sering berlarian kesana kemari tanpa terlihat lelah sama sekali; perilaku tantrum dan mudah marah, anak mudah tersulut emosinya ketika keinginannya tidak terpenuhi.

b. Perawatan yang dilakukan orang tua pada anak ADHD antara lain: pembatasan gadget; diet/pembatasan makanan; penerimaan keluarga; bantuan dalam aktivitas harian anak; pengawasan; terapi; pola asuh orang tua yang terdiri dari pola asuh otoriter dan permisif dikarenakan anak ADHD memiliki keterbatasan untuk menentukan pilihannya sendiri sehingga pola asuh demokratis tidak bisa diterapkan; dan hambatan perawatan, hambatan yang dialami orang tua adalah perilaku tantrum anak, dan stigma negatif dari masyarakat.

\section{SARAN}

a. Saran bagi pemerintah, peningkatan program bantuan dana, sarana prasarana untuk pengadaan pendidikan dan terapi pada anak ADHD.

b. Saran bagi pemangku kesehatan setempat untuk melakukan program skrining dan sosialisasi perkembangan pada usia bayi.

c. Saran untuk peneliti selanjutnya untuk meneliti mengenai pengembangan isntrumen deteksi ADHD yang dapat digunakan pada anak usia kurang dari 1 tahun.

\section{UCAPAN TERIMA KASIH}


Penulis ucapan terima kasih kepada pihak-pihak yang mendukung penulisan artikel ini antara lain Universitas Kusuma Husada Surakarta atas dukungan dana hibah internal dan Partisipan penelitian yang senantiasa memberikan respon yang baik untuk terlaksananya penelitian ini, serta pihak-pihak terkait dalam penelitian.

\section{REFERENSI}

ADHD Institute (2021) Epidemiology. Available at: https://adhdinstitute.com/burden-ofadhd/epidemiology/.

Afiyati and Rahmawati (2014) Metodologi Penelitian Kualitatif dalam Riset Keperawatan. Jakarta: Rajawali Press.

Alkaff, M. et al. (2019) 'Android Based Expert Sistem To Detect Types of Adhd', Jurnal Teknologi Informasi dan Ilmu Komputer (JTIIK) Vol., 6(2), pp. 135-140. doi: 10.25126/jtiik.201961265.

Andarul, M. T. (2020) Proses Penerimaan Orang Tua Yang Memiliki Anak Dengan Attention Deficit Hyperactivity Disorder $(A D H D)$ Universitas Katolik Soegijapranata Semarang. Available at:

http://repository.unika.ac.id/24767/.

Apriliantina, D. H., Tri Peni, S. and Laili, S. I. (2019) 'Penaruh Bermain Playdough Terhadap Kemampuan Motorik Halus Pada Anak Attention Deficit/Hyperactivity Disorder', http://repository.stikes-ppni.ac.id/,

5(7), pp. 21-36. Available at: http://repository.stikes-

ppni.ac.id:8080/xmlui/bitstream/hand le/123456789/201/Dhika Hariya Apriliantina.pdf?sequence $=1$ \&isAllo wed $=y$.

Astini, P. S. N., Utami, K. C. and Parwati, K. F. (2014) Pengalaman Orang tua Dalam Merawat Anak Gangguan Pemusatan Perhatian dan Hiperaktivitas. Politeknik Kesehatan Denpasar. Available at: http://poltekkesdenpasar.ac.id/files/JURNAL GEMA
KEPERAWATAN/JUNI 2015/Putu Susy Natha Astini.pdf.

Barkley, R. A. (2018) Attention-Deficit Hyperactivity Disorder Fourth Edition. A Handbook for Diagnosis and Treatment. 4th edn. New York: Guilford.

Camelia, R., Wijayanti, H. S. and Nissa, C. (2019) 'Studi kualitatif faktor yang mempengaruhi orang tua dalam pemberian makan anak autis', Jurnal Gizi Indonesia (The Indonesian Journal of Nutrition), 7(2), pp. 99108. doi: 10.14710/jgi.7.2.99-108.

Center for Disease Control and Prevention (2020) Data and Statistics About ADHD. Available at: https://www.cdc.gov/ncbddd/adhd/da ta.html.

Creswell, J. W. (2013) Edisi Ketiga, Research Design: Pendekatan Kualitatif, Kuantitatif dan Mixed. Yogyakarta: Pustaka Pelajar.

Fallupi, D. R. (2018) Kemampuan Berbicara Pada Anak Berkebutuhan Khusus (ABK) Usia 11-15 Tahun: Kajian Psikolinguistik, Unpad Repository. Universitas Padjajaran. Available at: https://repository.unpad.ac.id/frontdo or/index/index/year/2020/docId/1441 5.

Hakim, M. F. (2020) 'Giving Positive Reinforcement to Reduce Aggressiveness in Children with ADD : Pemberian Reinforcement Positive Untuk Menurunkan Agresivitas Pada Anak GPPH', 8, pp. 1-5. doi: 10.21070/icecrs2020588.

Hasanah, H. W., Fatmawati and Marlina (2018) 'Peningkatan Ketahanan Duduk dan Pengurangan Perilaku Meninggalkan Tempat Duduk melalui Teknik Time Out pada Anak Attention Deficit Hyperactivity Disorder', Jurnal Pendidikan Kebutuhan Khusus, 2(1), pp. 26-31.

Indayani and Ardhianti, M. (2014) 'Struktur Kalimat Dasar Bahasa Indonesia pada Anak ADHD (Attention Deficit Hiperactiv Disorder)', ICETA 5, (May 2014), pp. 202-209. Available at: https://karyailmiah.unipasby.ac.id/wp 
-content/uploads/2018/03/artikel3.pdf.

Irwin, L. N. et al. (2021) 'Activities of daily living and working memory in pediatric attentiondeficit/hyperactivity disorder (ADHD)', Child neuropsychology : a journal on normal and abnormal development in childhood and adolescence, 27(4), pp. 468-490. doi: $10.1080 / 09297049.2020 .1866521$.

Karimzadeh, M. et al. (2020) 'Experiences and worries in mothers with children suffering from ADHD: A Grounded Theory Study', Caspian Journal of Pediatric, 6(1), pp. 390398. Available at: http://caspianjp.ir/article-1-115en.pdf.

Kaunang, N., Munayang, H. and M.D.Kaunang, T. (2016) 'Pola asuh pada anak gangguan pemusatan perhatian dan hiperaktivitas di kota Manado', Jurnal e-Clinic (eCl), 4. Available at: https://ejournal.unsrat.ac.id/index.ph p/eclinic/article/view/12796/12386.

Novriana, D. E., Yanis, A. and Masri, M. (2014) 'Artikel Penelitian Prevalensi Gangguan Pemusatan Perhatian dan Hiperaktivitas pada Siswa dan Siswi Sekolah Dasar Negeri Kecamatan Padang Timur Kota Padang Tahun 2013', Jurnal Kesehatan Andalas, 3(2), pp. 141146. Available at: http://jurnal.fk.unand.ac.id/index.php /jka/article/view/52/47.

Petrauskas, V. M. (2014) An Examination of Fine Motor Control In Children with ADHD. University of Windsor. Available at: https://core.ac.uk/download/pdf/7277 0914.pdf.

Resmisari, R. (2016) 'Penerapan Metode ABA ( Applied Behavior Analysis ) untuk Meningkatkan Kontak Mata pada Anak dengan Gangguan Autis : Sebuah Laporan Kasus', 2nd Psycology \& Humanity, pp. 19-20. Available at: mpsi.umm.ac.id/files/file/374-378

Rizki Resmisari.pdf.

Rizky, E., Noor, I. and Fadhila, M.
(2020) 'Faktor Psikologis Yang Mempengaruhi Proses Terapi Anak Dengan Autisme', Jurnal Al-Husna, 1(1), pp. 1-24. doi: 10.1234/jah.v1i1.3513.

Setianingsih, S., Ardani, A. W. and Khayati, F. N. (2018) 'Dampak Penggunaan Gadget Pada Anak Usia Prasekolah Dapat Meningkatan Resiko Gangguan Pemusatan Perhatian Dan Hiperaktivitas', Gaster, XVI(2), pp. 191-205. Available at: http://jurnal.aiskauniversity.ac.id/index.php/gaster/arti cle/view/297.

Subandi, A. and Rusana (2014) 'Pengalaman Orang Tua dalam Mengasuh Anak dengan Attention Deficit Hyperactive Disorders (ADHD)/Hiperaktif', Jurnal Kesehatan Al-Irsyad (JKA), V(1), pp. 50-60. Available at: http://jka.stikesalirsyadclp.ac.id/inde x.php/jka/article/view/10.

Syamsuddin (2013) 'Mengenal Perilaku Tantrum Dan Bagaimana Mengatasinya', Informasi, 18(02), pp. 73-82.

Tanoyo, D. P. (2013) 'Diagnosis dan Tata Laksana AttentionDeficit/Hyperactivity Disorder', EJournal Medika Udayana, 2(7), pp. 1-19. Available at: http://download.portalgaruda.org/arti cle.php?article $=82563 \& \mathrm{val}=970$. 